\title{
Jerzy Syryjczyk
}

\section{Pojęcie ekskomuniki w świetle zadań}

pastoralnych Kościoła w Projekcie prawa karnego z $1973 \mathrm{r}$. oraz w Kodeksie Prawa Kanonicznego z 1983 r.

Prawo Kanoniczne : kwartalnik prawno-historyczny 32/1-2, 127-156

1989

Artykuł został zdigitalizowany i opracowany do udostępnienia w internecie przez Muzeum Historii Polski w ramach prac podejmowanych na rzecz zapewnienia otwartego, powszechnego i trwałego dostępu do polskiego dorobku naukowego i kulturalnego. Artykuł jest umieszczony w kolekcji cyfrowej bazhum.muzhp.pl, gromadzącej zawartość polskich czasopism humanistycznych i społecznych.

Tekst jest udostępniony do wykorzystania w ramach dozwolonego użytku. 


\section{POJĘCIE EKSKOMUNIKI \\ W SWIETLE ZADAN PASTORALNYCH KOSCIOLA W PROJEKCHE PRAWA KARNEGO Z $1973 \mathrm{R}$. ORAZ W KODEKSIE PRAWA KANONICZYYGO Z 1983 R.}

Tresc: - Wistęp. - I. Ekskomunika w Projekcie z 1973 r.: 1. Przesłanki nowego pojęcia ekskomuniki. 2. Skutki ekskomuniki w świetle ocen pastoralnych. - II. Eksskomunika w Kodeksie Prawa Kanonicznego z 1983 r.: 1. Ekskomunika jako środek poprawy przestępcy. 2. Ekskomunika a sakrament pokuty. -- Wnioski końcowe.

\section{Wstęp}

Od początku prac nad reformą prawa kościelnego powszechnie postulowano, aby przyszły Kodeks byl bardziej duszpasterski niż wylażały to przepisy Kodeksu z 1917 r. Postulat ten mial swoje podłoże w pastoralnym charakterze Soboru Watykańskiego II, a ponadto podyktowany byl słabnięciem w tym względzie przydatności obowiązującego prawa ${ }^{1}$. Nic też dziwnego, że orientacja pastoralna stała się ideą przewodnią również w procesie odnowy prawa karnego. Wyraz temu daje przedmowa do Projektu prawa karnego z 1973 roku, gdzie czytamy, iż przy opracowywaniu schematu nowych ustaw karnych w najwyższym stopniu kierowano się racjami duszpasterskimi (pastorales rationes summopere promote sunt) ${ }^{2}$. Z regułą tą wiąże się również uwaga, że kanoniczne prawo kaüne nigdy nie może naruszać zasady chrześcijańskiego milosierdzia Graz pozostawać w sprzeczności z dzialalnością pastoralną Kościoła 3.

Powyższa zasada - która niezmiennie przyświecala reformie kościelnego prawa karnego - całkowicie odmiennie została wy-

1 R. Sobański, Idee przewodnie nowego Kodeksu Prawa Kanonicznego, $w$ : Duszpasterstwo $w$ świetle nowego Kodeksu Prawa Kanonicznego. Praca zbiorowa pod red. J. Syryjezyka, Warszawa 1985 , s. $49-51$.

2 Pontificia Commissio Codici Iuris Canonici Recognoscendo, Schema documenti quo disciplina sanctionum seu poenarum in Ecclesia latina denuo ordinatur. Praenotanda, Typis Polyglottis Vaticanis 1973, s. 5 .

${ }_{3}$ Tamże, s. 5. Por. 5 . Nigro, Le sanzioni nella Chiesa come tutela communione ecclesiale, w: La nuova legislazione canonica, Pontificia Universitas Urbaniana, Roma 1983, s. 423-435. 
rażona w Projekcie z 1973 r. i Kodeksie Prawa Kanonicznego z 1983 roku. Zróżnicowany charakter duszpasterski prawa karnego uwidacznia sie zwlaszcza w pojęciu ekskomuniki (z punktu widzenia jej skutków), w obecnym prawie odmienınym od tego, które zaproponowano we wspomnianym Projekcie. Chociaż od opublikowania Projektu z 1973 r. mija juz 15 lat, nadal nie wygasa dyskusja tocząca sie wokól problemów teologicznych, prawnych i pastoralnych, jakile wywołuje przedłozone w nim rozwiązanie dotyczace kary ekskomuniki. Ponieważ przydatność pastoralna stanowi fundamentalne kryterium oceny ustaw kościelnych 4 , w tym także karnych, vydaje się, iż uzasadnione jest szczególne zwrócenie uwagi na przydatność duszpasiterską jednej z najsurowszych kar w Kościele, jaką jest ekskomunika. Skutki ekskomuniki co juz zostalo powiedziane - w Kodeksie z 1983 r. różnią się od jej skutków przedstawionych w Projekcie z 1973 r. Powstają wobec tego inne problemy duszpastersirie, podyktowane odmiennościa tych rozwiązań. Poniższe uwagi mają służyć naświetleniu zagadnień pastoralnych związanych z kara ekskomuniki w Projelacie z 1973 r. i w Kadeksie z $1983 \mathrm{r}$.

\section{Ekskommika w Projokcie z 1973 r.}

\section{Przestanki nowego pojeccia ekskomuniki}

Przygotowywanie projektów prawa karnego rozpoczęlo sie od sesji zespolu roboczego konsultorów (coetus studii de iure poenali) mającej miejsce w dniach 28-29 XI 1966 r., podczas której dokonano ogólnych ustaleń, jakimi mależy kierować się, reformując prawo karne. Pozwolily one na opracowanie pierwszych wstępnych projektów kanonicznego prawa karnego ${ }^{5}$; właściwe jednak prace, bardziej już ukierunkowane, rozpoczęly się w 1967 r. po uchwaleniu przez Synod Biskupów Zasad odnowy Kodeksu Prawa Kanonicznego ${ }^{6}$. Byly to ujęte w 10 punktach wytyczne, którymi miała sie kierować Komisja Kodyfikacyjna. Dyrektywy te, zatwierdzone przez papieża Pawła VI, mialy charakter ogólnych zasad i odnosily się do calego Kodeksu, jednakże niektóre z nich zwlaszcza wytyczne zawante $w$ punkcie 9 - wprost odnosily sie do reformy prawa karnego. Pozostale zasady odnowy Kodeksu Prawa Kanonicznego musiano przystosować do specyficznego dzialu

${ }^{4}$ R. Sobański, art. cyt., s. 50.

5 Communicationes 2 (1970) 99-107. Przebieg prac nad reforma prawa karnego podaje również W. Gór alski, Kodyfikacja prawa w Kosciele lacinskim po Soborze Watykanskim II, Plock 1983, s. 78-80.

- Principia quae Codicis Iuris Canonici recognitionem dirigant, Communicationes i (1969) 77---85. Tłumaczenie polskie: Posoborowe Prawodawstwo Kościelne. Wyd. E. Sztaf row ski, $\imath$. III, z. 3, Warszawa 1971 , s. $5-27$. 
prawa kościelnego, jakim jest prawo karne. Wypracowano więc pewne ogólne założenia, do których należy zaliczyć następujące:

1) prawo karne winno zachować wierność nauce Soboru Watykańskiego II;

2) dyscyplinie karnej ma przyświecać orientacja duszpasterska;

3) prawo karne należy ograniczyć tylko do zakresu zewnętrznego (totum ius poenale ad externum tantum forum limitatum est);

4) w przyszłym Kodeksie kary należy zredukować do koniecznego minimum;

5) normy prawne nie powinny zawierać definicji ustawowych oraz $z$ punktu widzenia techniki legislacyjnej mają się cechować jednolita terminologią;

6) należy poszerzyć pole dla ustawodawstwa partykularnego oraz ograniczyć powszechne prawo karne obowiazujące w calym Kosciele 7.

W Zasadach odnowy Kodeksu Prawa Kanonicznego uchwalonych przez Synod Biskupów w 1967 r. czytamy również: „W Kodeksie Prawa Kanonicznego musi istnieć coskonała harmonia między zakresem zewnętrznym i wewnętrznym, aby uniknąc wszelkiego konfliktu między jednym i drugim zakresem lub przynajmniej ograniczyć go do minimum. Należy się o to zatroszczyć w sposób szczególny w zakresie prawa sakramentalnego i karnego" 8. Powiazzanie prawa karnego z zakresem wewnętrznym niesie ze soba poważne niebezpieczeństwo. M. Myrcha uważa, iż ,na skutek szczodrobliwosci dokonanych w zakresie wewnętrznym może powstać konflikt między zakresem zewnętrznym i wewnętrznym $z$ uwagi na to, że nie zawsze będzie obowiązywać w zakresie zewnętrznym to, co zostalo dokonane w zakresie wewnętrznym lub to, czego nie będzie można udowodnić w zakresie zewnętrznym" 9. Wspomniany konflikt na gruncie prawa kannego może rodzić się wtedy, gdy w zakresie wewnętrznym kara nie istnieje lub została odpuszczona, a władza zakresu zewnętrznego sądzi o tym coś wręcz przeciwnego. Oprócz tego może zachodzić poważna różnica pomiędzy osądem władzy kościelnej dokonanym w jednym i drugim zakresie 10 . Wydaje się, że w dziedzinie spraw karnych surowszy sąd o sprawcy

7 Schema documenti quo disciplina sanctionum seu poenarum in Ecclesia latina denuo ordinatur. Praenotanda, s. 5 ns.; F. Nigro, art. cyt., s. 423-438; J. K Kuk ows ki, Nowe prawo karne Kościola kacińskiego, Ateneum Kapłańskuie 76 (1984) s. 267-268.

${ }_{8} \mathrm{Nr} 2,2$; Posoborowe Prawodawstwo Kościelne, t. III, z. 3, s. 10.

9. M y $\mathrm{rcha,} \mathrm{Niektóre} \mathrm{aspekty} \mathrm{prawa} \mathrm{karnego} w$ Kodeksie $z$ 1983 roku, 'w: Duszpasterstwo w świetle nowego Kodeksu Prawa Kanonicznego, s. 260.

${ }_{10} \mathrm{P}$. H $\mathrm{u}$ izing, De iudicio poenali in foro poenitentiali, Periodica 75 (1986), s. 256.

\section{9 - Prawo Kanoniczne}


$z$ reguky wydawany jest w zakresie zewnętrznym. Za wnioskiem tym przemawiają następujące racje:

1) W zakresie wewnętrznym winę zawsze należy penitentowi udowodnić. Odmiennie natomiast sprawa ta przedstawia się w zakresie zewnętrznym - tu bowiem z zewnętrznego przekroczenia ustawy karnej domniemywa się winę lub paczytalność sprawcy 11.

2) Poniewaz kara $z$ istoty swojej stanowi reakcję spoleczną skierowana przeciwko przestępcy, $z$ natury rzeczy odsuwana jest przez winnego bez względu na to, w jakim zakresie sprawę się rozstrzyga.

3) Spowiednik osądzający sprawce w zakresie wewnętrznym nie ma takich możliwości i środków do wywiązania się z ciążącego na nim obowiązku, jakie posiada sędzia wykonujący swoją wladzę w zakresie zewnętrznym 12 .

$\mathrm{Z}$ punktu widzenia pastoralnego wszystko to stwarza równiez niekorzystną sytuację zarówno dla penitenta, jak i spowiednika. Niektórzy kanoniści uznali, iż środkiem zaradczym przeciwko tym trudnosiciom duszpasterskim będzie calkowite zniesienie kar latae sententiae 13. Wówczas zakres sakramentalny zostanie uwolniony od prablemów prawa kainego, a wymiar i zwalnianie $z$ kar dokonywać się będzie iylko w zakresie zewnętrznym. Chodziło więc o ograniczenie prawa karnego do zakresu zewnętrznego zarówno w funkcji ustawodawczej, jak i wykonawczej, czyli sądowego i administracyjnego wymiaru kar oraz zwalniania $z$ tychze. W ten sposób kościelne prawo karne upodobniłoby się do państwowych systemów karnych przy jednoczesnym zachowaniu swojej specyfiki. Postulat ten zostal jednak odrzucony w Zasadach odnowy Kodeksu Prawa Kanonicznego, gdzie czytamy: „Jeżeli idzie o kary latae sententiae, to chociaz wielu proponowało calkowite ich zniesienie, jednak myśl jest taka, by je ograniczyć tylko do nielicznych wypadków, owszem przewidzieć je za bardzo wyjątkowe i ciężkie przestępstwa" 14 .

11 M. Myrcha, Problem winy w karnym ustawodawstwie kanonicznym, Prawo Kanoniczne 17 (1974) nr 3-4, s. 155-156.

12 A. Scheuermann, Erwägungen zur kirchlichen Strafrechtsreform, Archiv für katholisches Kirchenrecht 131 (1962), s. 393.

${ }_{13} \mathrm{~J}$. Arias, Las penas , latae sententiae": actualidad o anacronismo, w: Diritto, persona e viata sociale. Scritti in memoria di Orio Gi a c chi, vol. II, Miliano 1984, s. 5-27; V. De Pa ol is, De legitimitate et opportunitate poenarum latae sententiae in iure poenali canonico, Perioidica 62 (1973), s. 319-373; Tenże, Totum ius poenale ad externum tantum forum limitatum est, Periodica 65 (1976), s. 297-315; P. Huizing, Delicte und Strafen, Concilium 3 (1967) nr 8, s. 297-3.15; F. Mc MI a nus, The Internal Forum, w: Acta Conventus Internationalis Canonistarum, Roma 1970, s. 251-261; V. R a mal1o, Derecho penal canónico y libertad religiosa, Revista Española de Derecho Canónico $28(1972)$, s. $5-28$.

${ }_{14} \mathrm{Nr}$ 9, 2; Posoborowe Prawodawstwo Kościelne, t. Irr, z. 3, 5. 25. 
Opracowujący prawo karne zespół konsultorów na czele z relatorem P. Ciprottim dostrzegl inną możliwość rozwiązania omawianego problemu. Chcąc uwolnić spowiednika i penitenta od trudności, jakie niesie powiązanie prawa karnego $z$ sakramentem pokuty, postanowiono przyjąć zasadę, że zwalnianie z kar zostanie ograniczone tylko do zakresu zewnętrznego. Wprowadzenie tej zasady wymagało jednak poczynienia zmian $w$ zakresie skutków, jakie sprowadza kara ekskomuniki i interdyktu personalnego. Postanowiono więc, że żadna z tych kar nie będzie zabraniała dostępu do sakramentu pokuty i namaszczenia chorych. Za rozwiązaniem tym przemawiały w pewnej mierze równiez Zasady odnowy Kodeksu Prawa Kanonicznego, w których czytamy: „Wysuwa się projekt, by kary były $z$ reguły (generatim) ferendae sententiae oraz wymierzane $i$ odpuszczane jedynie $w$ zakresie zewnętrznym"16.

Zgodnie z powyższym w kan. $16 \S 1$ Projektu z 1973 r. postanowiono, że ekskomunika w przyszłości nie będzie zabraniała dostępu do spowiedzi i uzyskania absolucji sakramentalnej penitentowi będącemu $w$ tej karze 15. Pomimo jednak uzyskania absolucji sakramentalnej ekskomunikowany nie może przystąić do Eucharystii, zanim $z$ kary nie zostanie zwolniony $w$ zakresie zewnętrznym. Propozycję przedłożoną w kan. 16 \& 1 Projektu uzasadmiały racje, do których zali.czyć należy zwłaszcza następujące:

$1^{\circ}$ naturalnym polem prawa jest zakres zewnętrzny, toteż oddzielenie kanonicznego prawa karnego od zakresu wewnętrznego sprawi, że będzie ono w większym stopniu spełniać funkcję właściwą prawu karnemu 17 ;

$2^{\circ}$ zwalnianie $z$ kar ograniczone tylko do zakresu zewnętrznego usuwa możliwość powstawania jakichkolwiek kolizji pomiędzy zakresem zewnętrznym i wewnętrznym ${ }^{18}$;

$3^{\circ}$ uwolni to $\mathrm{w}$ konsekwencji spowiednika i penitenta od trudnych i zawilych problemów związanych ze zwalnianiem z kar w sakramencie pokuty ${ }^{19}$;

$4^{\circ}$ kanoniczne prawo karne nie będzie przeszkadzalo $w$ działalności pastoralnej Kościoła, a zadania te pozostawi innym dziedzinom prawa 20.

15 Tamże.

${ }^{16}$ Kan. $16 \quad \S 1$ - „Excommunicatio vetat: b) Sacramenta exceptis poenitentiale et infirmorum unctione recipere...". To samo dotyczy takzie interdyktu personalnego - kan. $17 \S 1$, b.

${ }_{17} \mathrm{~V}$. D e $\mathrm{P}$ aloli $\mathrm{s}$, Totum ius poenale ad externum tantum forum limitatum est, s. 304-305.

${ }_{18} \mathrm{M}$. M y rcha, Niektóre aspekty prawa karnego $w$ Kodeksie $z$ 1983 roku, s. $261-262$.

19 Por. P: H uizing, De iudicio poenali in foro poenitentiali, s. 269.

$20 \mathrm{~V}$. De Paolis, Totum ius poenale ad externum..., s. 314. 
Propozycja zmian w zakresie skưków ekskomuniki wywołała wśród kanonistów szeroką dyskusję, która trwa aż po dzień dzisiejszy 21. Opinie autorów $w$ tej materii są zróżniconwane. Jedni $z$ nich aprobuja i uzasadniają słuszność zaproponowanych zmian 22, inni natomiast występują ze zdecydowaną ich krytyką twierdząc, ze forma ekskomuniki w Projekcie z 1973 r. jest niemożliwa do przyjধ̨cia. Ekskomunice tej zarzuca się, że

$1^{\circ}$ jest niezgodna $z$ doktryną Soboru Watykańskiego II, tzn. pozostaje w sprzeczności $z$ soborową nauką o Kościele i wypowiedziami na temat sakramentu pokuty ${ }^{23}$;

$2^{\circ}$ sprzeciwia się wytycznym, które podają Zasady odnowy Kodeksu Prawa Kanonicznego opracowane przez Synod Biskupów w 1967 r., ściślej zaś mówiąc — jest wyrazem błędnego odczyłania podanych tam regul odnowy prawa karnego 24;

$3^{\circ}$ nie uwzględnia zasad teologicznych 25 i zaprzecza tradycyjne-

21 Ogólny zarys tej dyskusji przedstawia: P. Hemperek, Ograniczenie wtadzy rozgrzeszania $z$ racji grzechów $i$ cenzur kościelnych $w$ świetle prac nad reforma prawa kanonicznego, Rocznilki Teologiczno-Kanoniczne 28 (1981), z. 5, s. 55-57; P. Huizing, De iudicio poenali in foro poenitentiali, s. $259-263$.

$22 \mathrm{Za}$ tym, aby cenzury nie zabranialy dostępu do sakramentu pokuty, opowiedzieli się: J. IM. Go nz al e z de I Valle, El sacramento de la penitencia. Fundamentos historicos de su regulacion actual, Pam. plona 1972 , s. 228; P. Ciprotti, Il diritto penale della Chiesa dopo il Concilio, Ephemerides Iuris Canonici 26 (1970), s. 91-106; Tenże, Animadversiones ad Schema "De iure poenali canonico", Prawo Kanoniczne 19 (1976) nx 1-2, s. 6-7; V. De Palol is, De recognoscendo iure poenali canonico, Peniodica 63 (1974), s. 60-67; Tenże, Animad̄versiones ad ,Schema documenti quo disciplina sanctionum seu poenarum in Ecclesia latina denuo ordinatur", Periodica 63 (1974), s. $497-503$.

Ostatnio polemike $\mathrm{z}$ przeoiwnikami tego stanowiska podjal $P$. $\mathrm{Hu} \mathrm{zing}$, De iudicio poenali in foro poenitentiali, s. 263-266.

${ }_{23} \mathrm{~K}$. Mörs dorf, Zum Problem der Exkommunikation. Bemerkungen zum Schema Documenti quo disciplina sanctionum seu poenarum in Ecclesia Latina denuo ordinatur, Archiv für katholisches Kirchenrecht 143 (1974), s. 64-66; R. Sob ań sk i, O niektórych problemach prawa karnego. Uwagi na marginesie reformy, Collectanea Theologica 44 (1974), f. 4, s. 174 ins.; F. Coccopalm e rio, Natura ecclesialis sacramenti Paenitentiae et actualis recognitio iuris poenalis, Periodica 64 (1975), s. 224-230; M. M a n a nares, Por que el Derecho de la Iglesia? w: Institutiones canonicas y reordinacion juridica, Salamanca 1979 , s. 75-113; G. Franse n, Le nouveau Code de droit canonique. Présentation et réflexions, Revue Théologique de Louvain 14 (1983), s. $275-288$.

$24 \mathrm{~K}$. Mörsdorf, Zur Problem der Exkommunikation, s. 66-67.

25 A. Scheuermann, Das Schema 1973 für das kommende kirchliche Strafrecht, Archiv für katholissches Kirchenrecht 1.43 (1974), s. 19-20; F. Coccopalmerio, Sacramentum Paenitentiae et ius poenale in structura Ecclesiae, Periodica 64 (1975), s. 394-404; Tenże, De natura iuris poenalis Ecclesiae, Periodica 65 (1976), s. 317-330; $343-346$. 
mu pojmowaniu ekskomuniki, które sięga czasów nowotestamentalnych 26;

$4^{\circ} \mathrm{z}$ pastoralnego punkitu widzenia jest nieprzydatna, a nawet wręez szkodliwa.

\section{Skutki ekskomuniki $w$ świetle ocen pastoralnych}

W zarzutach podnoszonych przeciwko ujęciu ekskomuniki w Projekcie z 1973 r. wykkazuje się, że z punktu widzenia racji pastoralnych jest ona niemożliwa do przyjęcia $w$ ustawodawstwie kościelnym. Ekskomunika, która dopuszcza do sakramentu pokuty i jednocześnie zabrania dostępu do Eucharystii, zaprzecza tradycyjnej koncepcji absolucji sakramentalnej, przez którą grzesznilk dostępuje pojednania z Bogiem i Kościołem. Absolucja otrzymana w sakramencie pokuty przywraca prawo do prizymowania Eucharystit, rozgrzeszenie dziala przeto w zakresie (w zasięgu) zgromadzonej wspólnoty eucharystycznej. Forma ekskomuniki w Projekcie $z 1973$ r. jest więc sprzecznością sama w sobie, albowiem w Kościele nie może równocześnie egzystować ekskomunika i pojednanie. W ujęciu Projektu z 1973 r. dochodzi do rozdziału, aby nie powiedzieć - przepaści pomiędzy Kościolem prawnie ukonstytuowanym a jego wspólnotą duchową ${ }^{27}$. Idąc dalej tym tokiem rozumowania można rzec, że ekskomunika ta prowadzi do rozdźwięku pomiędzy "Kościołem miłości” i „Kościołem prawa”, oprócz tego u wiernych może zrodzić się przekonanie, iż zasadą chrześcijańskiej miłości i miłosierdzia kieruje się tylko wladza zakresu wewnętrznego wykonywana w sakiramencie pokuty, władzy kościelnej wykonywanej w zakresie zewnętrznym natomiast przyświecają inne zasady.

Rozwiązanie przedłożone w Projekcie z 1973 r. może zakłócać przekonanie wiernych, że absolucja sakramentalna przywraca prawo do udziału we wspólnocie eucharystycznej. Stąd może rodzić się $u$ nich podejrzenie lub fakszywa opinia, jakoby $w$ sakramencie pokuty dokonywało się pojednanie tylko z Bogiem, ale nie z Kościokem, co jest przecież sprzeczne $z$ istota absolucji sakramentalnej 28. Stąd zaś juz tylko krok do dalszych błędnych wniosków, iż w Kościele wladza wykonywana w zakresie wewnętrznym różni się W sposób istotny od władzy zakresu zewnętrznego. Jak to jest możliwe - pyta A. Soheuerman 29 - aby kitoś prawnie w za-

${ }^{26}$ R. Sobański, O niektórych problemach prawa karnego, s. 175.

${ }^{27} \mathrm{~K}$. Mörs dorf, Zum Problem der Exkommunikation, s. 65-66; R. Sobański, O niektórych problemach prawa karnego, s. 174-175.

${ }^{28} \mathrm{~F}$. Coccopalmerio, Natura ecclesialis sacramenti Paenitentiale et actualis recognitio iuris poenalis, s. 224, 229; Tenże, Momentum ecclesiale in sacramento reconciliationis, Monitor Ecclesiasticus 101 (1976), s. $43-48$.

* Das Schema 1973 für kommende kirchliche Strafrecht, s. 20. 
kresie wewnętrznym zostal rozgrzeszony i jednocześnie prawnie w zakresie zewnętrznym odmówiono mu Eucharystii? W abu zakresach wrkonywana jest przecież jedna i ta sama wladza Kościoła - auctoritas spiritualis. Jedyna zaś różnica między nimi polega tylko na sposobie wykonywania owej władzy.

Praktyczną konselkwencją ekskomuniki wedkug Projektu z 1973 roku, łatwa zreszta do przewidzenia, będzie reakcja wiernych: nie będą oni widzieli potrzeby korzystania z sakramentu pokuty, skoro po otrzymaniu rozgrzeszenia nie można przystąpić do Eucharystii 30 . Od strony duszpasterskiej taka ekskomunika jest nie tylko pastoralnie nieprzydatna, ale wrecz szkodliwa, gdyz oddala wiernych od sakramentu pokuty.

Moim zdaniem przeciwko formie ekskomuniki przedstawionej w Projekcie z 1973 r. przemawia także i to, iz wypacza ona istotę pojednania w Kościele, traktując je w sposób statyczny. Pojęcie pojednania natomiast ma w rzeczywistości charakter mesjański, eklezjalny i dynamiczny ${ }^{31}$. Statyczne ujęcie absolucji sakramentalnej, czyli pojednania z Bogiem i z Kościołem, bez możliwości przyjęcia Eucharystii prowadzi do wniosku, że po otrzymaniu rozgrzeszenia Eucharystia staje się zbędna, skoro pojednanie już się dokonało. Stąd też może nie być zauważana przez wiernych potrzeba uwolnienia się od kary w zakresie zewnętrznym. A pojednanie - jako rzeczywistość eklezjalna - dokonuje się przeciez $\mathrm{w}$ dwóch sakramentach: w Eucharystii oraz w sakramencie pokuty i rzeczywistości tej nie może wypaczać kara kościelna. W Świetle powyższego nasuwa się wiosek, że propozycja ekskomuniki przedstawiona w Projekcie z $1973 \mathrm{r}$. w praktyce nie tylko wiernych oddala od sakramentu pokuty i Eucharystii, ale takze prowadzi do spłycenia sensu pojednania z Bogiem i Kościołem, które dokonuje się $w$ powyższych sakramentach.

Rozgrzeszenie i zakaz przyjmowania Eucharystii stwarza tez inne niekorzystne $z$ punktu widzenia pastoralnego konsekwencje. W tej perspektywie $z$ jednej strony grzech redukuje się do spraw indywidualnych $i$ czysto prywatnych, tak że zatraca on wlaściwe odniesienie do wispólnoty kościelnej (communio), z drugiej zaś strony uwypukla się $w$ sposób przesadny znaczenie przestęstwa i kary w relacji do dobra wspólnego w Kościele ${ }^{32}$.

${ }^{30}$ F. N idgro, art. cyt., s. 456.

s1 Ch. Duquoc, Pojednanie rzeczywiste i pojednanie sakramentalne, Concilium 1971, Poznań-Warszarwa 1972, s. 9-17.

${ }^{32} \mathrm{~F}$. N i g r o, art. cyt., s. 455-456. Odmienny pogląd na ten temat wypowiada De Pa olis. Twierdzi on, że ekskomunika w Projekcie z 1973 r. nie przyczynia się do sprowadzenia sakramentu pokuty na płaszczyznę spraw indywidualnych. Jego zdaniem powyższe stanowisko uzasardniają następujące argumenty: 1) Dyscyplina pokutna nie utożsamia się z prawem karnym. Sa to calkowicie dwie odrębne sprawy; 2) Z tej przyezyny, że odpuszczanie grzechów dokonuje się w zakresie 
Prawo karne i ekskomunika w Projekcie z 1973 r. nie spełniają wreszcie właściwych sobie funkcji pastoralnych 33. Eksikomunika jako kara poprawcza lub lecznicza jest narzędziem działalności pastorainej Kościoła $\mathrm{i}$ w ostateczności ma síużyć nawróceniu i poprawie opornєgo przestępcy - grzesznika. Charakteru tego w ogóle nie posiada ona w Projekcie z 1973 r. W świetle kan. 16 $\S 1$ ekskomunika nie zmierza do poprawy przestępcy, albowiem jest on poprawiony już wtedy, gdy przystępuje do sakramentu pokuty - odsitępuje od uporu, nawraca się i poprawia. Można mówić o innych celach takiej ekskomuniki, jak naprawienie szkody, usunigcie zgorszenia, przykład dla inmych wiernych, ale wówczas nie będzie to kara poprawcza, lecz ekspiacyjna 31. Ekskomunika przestaje więc pełnić funkcje pastoralne, nie naklania do porzucenia uporu i podjęcia pokuty, lecz staje się przeszkodą w przyjmowaniu Eucharystii oraz pośrednio oddala od sakramentu pokuty.

Co można powiedzieć o niektórych pastoralnie negatywnych ocenach ekskomuniki zaproponowanej w Projekcie z 1973 r.? Nie ulega najmniejszej wątpliwości, że absolucja sakramentalna decyduje tak o pojednaniu z Bogiem, jak i z Kościołem oraz przywraca prawo przyjmowania Eucharystii. Odmowa tego prawa za karę (do czasu zwolnienia $z$ cenzury w zakresie zewnętrznyrn) nie może prowadzić do mylnego przeświadczenia, że rozgrzeszenie nie stanowi pojednania z Kościolem. Powyższe ujęcie tylko w pewnym sensie zakłóca tradycyjne pojmowanie absolucji sakramentalnej, w której zawiera się prawo do Eucharystii. Mówię „w pewnym sensie", gdyz zasada ta nie jest bezwzględna i dopuszcza wyjątki. Przewidywał je poprzedni Kodeks, czego wyrazem są kan. 855 i 225135 . Zgodnie z kan. 855 \& 2 otrzymanie absolucji sakramentalnej nie zawsze uprawnia do przyjęcia Eucharystii. W świetle zaś kan. 2251 chociazby ekskomunikowany zostal zwolniony $z$ cenzury $w$ zakresie wewnętrznym, to jednak przełozony zakresu zewnętrznego może żądać zachowania kary, odmawiając mu np. Eucharysiij, dopóki nie nastąpi jej odpuszczenie $w$ zakresie zewnętrznym. Podobną do kan. $85 \overline{5}$ zasadę wyrażają Normy duszpasterskie dotyczace udzielania generalnej absolucji sakramentalnej36. W nume-

wewnętranym, nie można wnicskowac, że pokuta sakramentalna w Kościele jest sprawą prywatną a nie publiczną. Zarówno zakres zewnętrzny, jak i wewnętrzny należą do prawa publicznego w Kościele; 3) Pokuta sakramentalna zawsze ma wymiar wspólnotowy: De recognoscendo iure poenali canonico, s. 66 .

33 Communicationes 7 (1975) 95.

34 F. Coccopalmerio, De natura iuris poenalis Ecclesiae, $s .330$.

35 P. Ciprotti, Animadversiones ad Schema ,De iure poenali canonico", s. 6 .

36 Normae pastorales circa absalutionem sacramentalem modo generali impertiendam; AAS 64 (1972) 510-514. 
rze 9 Norm duszpasterskich postanawia się: „Kto jest zgorszeniem dla wiernych, może - gdy szczerze zaluje $i$ zamierza na serio usunąć zgorszenie - otrzymać razem $z$ innymi absolucje sakramentalną. Jednakże nie powinien przystąpić do Komunii św..." 3 ?. Warunkiem otrzymania absolucji sakramentalnej jest odpowiednia dyspozycja penitenta, będącego zgorszeniem dla wiernych. Pomimo rozgrzeszenia, a więc dokonanego pojednania z Bogiem i z Kościołem, nadal obowiązuje zakaz przyjmowania Kornunii św.

Powyższe postanowienia prawne wyraźnie wskazują, że pojednanie sakramentalne nie zawsze zezwala na przyjęcie Eucharystii. Zakaz ten podyktowany jest dobrem ogólnym wiernych $\$ 8$ ma na celu usunięcie niebezpieczeństwa zgorszenia oraz skłonienie penitenta do poprawy. Dyspozycje te nie budzily jednak obaw czy też poważnych zastrzeżeń, ze u wiernych moga się rodzić falszywe opinie o znaczeniu absolucji sakramentalnej, albowiem dotyczyły one sytuacji wyjątkowych i uzasadnionych dobrem ogólnym wspólnoty kościelnej. Poważne obawy w tej materii powstaja natomiast w przypadku propozycji wyrażonej w Projekcie $z 1973 \mathrm{r}$, gdzie wyjątek ten przybiera postać reguky $w$ stosunku do kary ekskomuniki i interdyktu personalnego i nie jest uzasadniony niebezpieczenistwem zgorszenia. W konsekwencji taka ekskomunika zdaniem niektórych kanonistów - może zakłócać przekonanie wiernych, ze absolucja sakramentalna przywraca prawo do Eucharystii. Z poglądem tym polemizuje Huizing ${ }^{39}$, który twierdzi, że ekskomunika przewidziana w Projekcie z 1973 r. nie zakłóca w zasadzie przekonania wiernych o znaczeniu absolucji sakramentalnej. Jeżeli zaś taka sytuacja zaistnieje, to na pewno bardzo rzadko i tylko wtedy, gdy ktoś ukarany jest ekskomuniką lub interdyktem. Przekonanie elrskomunikowanego, iż absolucja sakramentalna przywraca mu prawo przyjmowania Komunii św., jest wówczas fałszywe i bezpodstawne. W świetle powyższego można powiedzieć, że obawy duszpasterskie dotyczące omawianej kwestii są raczej plonne. Nie oznacza to jednak, że ekskomunika w Projekcie z 1973 r. nie stwarza bardzo poważnych problemów natury pastoralnej.

Skutki omawianej ekskomuniki - kontynuuje Huizing ${ }^{40}$ - nie moga równiez sugerować wiernym, że $w$ sakramencie pokuty doksonuje się pojednanie $z$ Bogiem, ale nie z Kościołem. Spowiednik, udzielając rozgrzeszenia, działa jednocześnie w imieniu

37 Tfumaczenie polskie: E. Sztafrowski, Posoborowe Prawodawstwo Kościelne, t. V, z. 1, Warszawa 1974, s. 176-187.

${ }^{3} \mathrm{~V}$. D e $\mathrm{P}$ a o 1 is, De recognoscendo iure poenali canonico, s, 60-67; Tenże, Animadversiones ad "Schema documenti quo disciplina sanctionum seu poenarum in Ecclesia latina denuo ordinatur", s. 497-503.

${ }^{38}$ De iudicio poenali in foro poenitentiali, s. 266.

10 Tamże, s. $263-264$. 
Boga i Kościoła - aktem władzy kapłańskiej i kanonicznego upoważnienia otrzymanego od Kościoła. Pojednanie z Bogiem i z Kościołem $w$ sakramencie pokuty świadczy o uwolnieniu penitenta od winy grzechu, lecz nie stanowi uwolnienia od kar kościelnych. $\mathrm{Za}$ "winę grzechów” nakłada się przecież jaką̧ś pokutę, a więc absolucja od grzechów nie jest uwolnieniem od kar kościelnych.

Pozbawienie Eucharystii w omawianym wypadku ma charakter karny - jest wyrazem pozytywnej woli ustawodawcy kościelnego, pomimo kar kościelnych można bowiem żyć w jedności z Bogiem i Kościołem, czego wymowny przykład stanowi kara suspensy. Kara kościelna nie jest znakiem braku jedności z Kościołem, nie oznacza również nieprzyjaźni pomiędzy wspólnotą a przestępcą 41.

Prawo karne, a także kara ekskomuniki, nie musza również spełniać zadań lub funkcji pastoralnych - twierdzi De Paolis 42 albowiem $w$ Kościele środkom przymusu nie powinno się dawać pierwszeństwa przed innymi sposobami działalności duszpasterskiej, zwłaszcza przed nawróceniem przestępcy, które dokonuje się $\mathrm{w}$ sakramencie pokluty. Oddzielenie zakresu wewnętrznego od prawa karnego łącznie $z$ karą ekskomuniki daje ekskomunikowanemu calkowicie swobodny przystęp do trybunału milosierdzia. Nawrócenie jego staje się tym samym bardziej owocne i skuteczne, gdyż dokonuje się $\mathrm{w}$ sposób wolny, co w sakramencie pokuty zawsze jest wymagane. Ponadto Kościół poza tym sakramentem posiada inne środki i sposoby, za pomoca których zmierza do nawrócenia i poprawy grzeszników. Należą do nich na przykład: rada, zachęta, braterskie upomnienie, skarcenie itp. Chociaż $w$ karze ekskomuniki poprawa przestępcy i jego nawrócenie są wysuwane na plan pierwszy, nie jest to jednak zasadniczy jej cel. Wymiar kar $w$ Kościele nie służy nawracaniu wiernych, gdyż istotnym i whaściwym ich zadaniem jest zachowanie wspólnoty (servare comminionem), co nie wyklucza celów dodatkowych lub drugorzędnych.

Należy mocno podkreślić, iż kościelne prawo karne nie może calkowicie zrzec sie funkcji pastoralnej. Odsuwając je od zadań duszpasterskich, należałoby kary kościelne całkowicie odizolować od prawa sakramentalnego, a więc od wszystkuich sakramentów św., a nie tylko od sakramentu pokuty i namaszczenia chorych, jak to wyraził Projekt z 1973 r. Celem prawa kanonicznego jest budowanie i zabezpieczanie wspólnoty kościelnej, kary kościelne łącrnie $z$ ekskomuniką - są natomiast ostatecznym narzędziem

$41 \mathrm{~V}$. De $\mathrm{Pao} 1 \mathrm{is}$, Totum ius poenale ad externum tantum forum limitatum est, s. 311 .

42 Tamże, s. 309-312. 
lub środkiem przymusu w działalności pastoralnej Kościoła, stosowanym do osiągnięcia tychże celów.

Ekskomunika w Projekcie z 1973 r. z pewnością nie stanowiłaby zbyt wielkiego utrudnienia $w$ działalności duszpasterskiej, gdyż nie chce $z$ nua mieć zasadniczych powiązań. Przekazuje ją w większym zalkresie niż dotychiczas innym dziedzinom prawa, przez co staje się wyraźniej regulatorem zewnętrznych przejawów życia spolecznego $w$ Kosciele. Zatraca tym samym przydatnośc pastoralną, aby juz nie mówić o innych negatywnych w tym względzie konselzwencjach powyższego rozwiązania, o których wyżej byla mowa.

Wobec zdecydowanie ostrej krytyki wysuwanej pod adresem ujęcia ekskomuniki zaproponowanego w Projekcie z $1973 \because$ zespół konsultorów przygotowujacy prawo karne przekazal ten problem do rozstrzygnięcia Plenarnej Komisji Kardynałów w formie pytania: „Czy można zatrzymać pojęcie eksłomuniki, jakie podaje schemat, aby $z$ ogólnego zakazu przyjmowania saksramentów wlaściwego elsskomunice wyjąc sakrament pokuty i namaszczenia chorych?" 43. Komisja na swym posiedzeniu w dniach 24-27 V 1977 r. odpowiedziała na pytanie negatywnie 44 , czyli nie zgodzila "sie na zaproponowane pojmowanie skutków ekskomuniki. Należało więc powrócić do pojęcia ekskomuniki przyjętego w Kodeksie z 1917 r., gdzie kara ta zabrania przyjmowania wszystkich sakramentów świętych. To $z$ kolei implikowalo konieczność przewidzenia normy umożliwiajacej zwalnianie z cenzury podczas spowiedzi, zwlaszcza za przestępstwa tajne, gdy sprawcy trudno jest odłożyć przyjęcie sakmamentu pokuty do czasu zwolnienia z kary przez przelożonego $w$ zakresie zewnętrznym 45 .

Powrót do dyscypliny karnej, jaką wyraża Kodeks z 1917 r., niesie ze sobą wizje dawnych problemów pastoralnych, których kara ekskomuniki w szczególny sposób nastręczala w takich kwestiach jak:

$1^{\circ}$ możliwość powstawania konflitków pomiędzy zakresem zewnętrznym i wewnętrznym;

$2^{\circ}$ skomplikowany sposób zwalniania $z$ kar w sakramencie pokuty;

$3^{\circ}$ zbyt mocne obciążenie sumienia wiernych prawem karnym;

$4^{\mathrm{O}}$ priorytet kary przed innymi środkami działalności duszpasterskiej.

W świetle powyższego nasuwa sie pytanie, które retorycanie

43 Communicationes 9 (1977) 80.

44 Tamże, s. 2113. Przeciwko pojecciu ekskomuniki, w Projekcie $1973 \mathrm{r}$. opowi.edziało się 26 kardynałów, 3 głosowalo za utrzymaniem propozycji, 1 wstrzymaz się od glosu.

45 P. Hem perek, art. cyt., s. 57-58; M. M y r cha, Niektóre aspekty prawa karnego w Kodeksie $z 1983$ roku, s. 263-264. 
postawił De Paolis 46: jakie racje pastoralne przemawiają za tym, że ukarany np. ekskomuniką nie może przystąpić do sakramentu pokuty, zanim nie zostanie uwolniony od kary?

\section{Ckskomunika w Kodeksie Prawa Kanonicznego z 1983 r.}

1. Ekskomunika jako srodek poprawy przestępcy

Popxawa przestępcy ma doniosłe znaczenie dla każdej spoleczności, także dla Kościoła, który zmierza do uświęcenia wszystkich ludzi. Realizacje owego celu uniemożliwia grzech ciężki, jakim jest przestępstwo. Stąd też Kościól - prowadząc wszystkich do zbawienia - od początku swego istnienia zwalczal i zwalcza grzech przy pomocy różnych środków. Korzystając z przysługującej mu władzy, grzechem zajmuje się $w$ obu zakresach. W zakresie wewnętrznym dokonuje się to w sakramencie pokuty, natomiast $w$ zakresie zewnętrznym - między innymi poprzez prawo karne 47.

Współcześnie w walce $z$ grzechem i przestępstwem - jak to wymika $z$ kan. $1341 \mathrm{KPK} / 1983$ - na pierwszym miejscu stawiane jest oddziaływanie duszpasterskie, tzn. przepomiadanie Słowa Bożego, braterskie upomnienie, skarcenie, zachęta, rada, dobry przykład itd. Oprócz tego stosowane są środki prawne, do których zalicza sie przede wszystkim zakaz przystępowania do Eucharystit, zanim grzech nie zostanie odpuszczony w sakramencie pokuty (kan. 916). W ostateczności zaś, gdy przy pomocy wspomnianych środków nie można osiągnąć poprawy przestęcy, wyrównania naruszonej sprawiedliwości i naprawienia zgorszenia - Kościół posługuje się środkiem przymusu w postaci kar kościelnych 48. Najsurowszą spośród wszystkich przewidzianych w Kodeksie z $1983 \mathrm{r}$. jest ekskomunika, której cel pierwszorzędny stamowi poprawa przestępcy.

Niektórzy kanoniści 49 , nawiązując do deklaracji Soboru Watykańskiego II Dignitatis humanae, wystąpili z ostrą krytyką stosowania w Kościele środków przymusu w postaci kar. Ich zdaniem sankcją karną, w tym przypadku ekskomunika, nie można skłaniać nikogo do nawrócenia, gdyż sprzeciwia się to zasadzie poszano-

43 Totum ius poenale ad externum tantum forum limitatum est, s. 315 .

${ }_{46} \mathrm{M}$. IV y r cha, Problem grzechu $w$ karnym ustawodawstwie kanonicznym, Prawo Kanonliczne 29 (1986) $\mathrm{nr} 1-2$, s. 44.

${ }_{48} \mathrm{~V}$. De Paolis, De sanctionibus in Ecclesia. Adnotationes in Codicem: Liber VI, Romae 1986, s. 25-26.

${ }^{40} \mathrm{P}$. H uizing, Delicte und Strafen, s. 299; V. R a mallo, Dęrecho penal canónico y libertad religiosa, s. 5-7; $\mathrm{K}$. W a $\mathrm{f}$, Kirchliche Disziplin und heutiges kirchliches Leben, Concilium 11 (1975), s. $468-469$. 
wania wolności religijnej i wolności sumienia. Ponadto argumentują, że ofiarowane przez Boga Przymierze z Nim z natury swojej jest dla człowieka aktem wolnym, zmuszanie do nawrócenia stoi więc w jaskrawej sprzeczności z rzeczywistością zbawczą. W pogląach autorów ustosunkowujących się do tego zagadnienia wyróżnić można trzy stanowiska.

Zgodnie z opinią, którą wyrazili P. Ciprotti 50, V. De Paolis 61 i J. Arias ${ }^{\mathbf{2}}$, powyższy zarzut nie ma żadnego znaczznia, albowiem przez stosowanie sankcji karnych w Kościele nie zmierza się do nawracania wiernych w znaczeniu teologicznym. W prawie karnym chodzi tylko o nawrócenie lub poprawę przestępcy w sensie spoleczinym.

Wedlug poglądów drugiej grupy kanonistów, do których zalicza się przede wszystkim V. Ramallo 5 s i F. Coccopalmerio 54, kościelne prawo karne nie może wyrażac przymusu wobec przestępcy, lecz tylko w stosunku do przesíępstwa. Tego rodzaju przymus jest reakcją Kościoła, ktớry tylko deklaruje, że zachodzi poważna różnica pomiędzy wspólnotą sakramentalną a występną postawą jednostki. Pogląd ten wynika z błędnej interpretacji sankcji karnej w Kościele. Nie jest ona bowiem stwierdzeniem lub deklaracja, która świadczy o czyjejś niegodziwości. Kara zobowiązuje sprawcę do jej zachowamia $i$ to $w$ obu zakresach - zewnętrznym i wewnętrznym. Oprócz tego zwłaszcza cenzura skłania przestępce do spełnienia określonych warunków przewidzianych prawem, aby mógl otrzymać zwolnienie z kary

Najbardziej skrajne stanowisko $w$ powyższej materii zajeli P. Huizing 56 i K. Walf 57. Autorzy ci proponuja zastąpić prawo karne porządkiem dyscyplinarnym, którego celem byłaby samoobrona wspólnoty wiernych. Wedlug tej koncepcji należy odrzucić przymus społeczny $w$ Kościele jako sprzeczny z zasada wolności religijnej i wprowadzić system środków pokutnych o charakterze pastoralnym 58 . Koncepcja ta znosi więc rozróżnienie po-

50 Il diritto penale della Chiesa dopo il Concilio, s. 97-98.

51 Estne censura latae sententiae favorabilis ad deliquentis conversionem? Monitor Ecclesiasticus 101 (1976), s. 346-347.

${ }_{52}$ El sistema penal canonico ante la reforma del C.I.C., Ius Canonicum 15 (1975), s. 226-227.

53 Art. cyt., s. 9.

54 Il diritto penale della Chiesa: riflessioni e proposte, w: Problemi e prospettive di diritto canonico, ed. E. C appel 1 i ni, Brescia. 1977, s. $269-271$.

55 A. Borras, L'excommunication dans le nouveau code de droit canonique. Essai de definition, Paris 1987, s. 302.

${ }_{56}$ Delicte und Strafen, s. 298--302; Le droit d'exclure, Lumiere et Vie 141 (1979), s. $54-57$.

57 Art. cyt., s. $471-472$.

58 A. A rza, Derecho penal en la Iglesia, w: Investigationes Theologico-Canonico, Roma 1978 , s. $34-38$. 
między przymusem wykonywanym $\mathrm{w}$ Kościele $\mathrm{w}$ porządku pokutnym (sakramentolnym), w postępowaniu dyscyplinarnym oraz postępowaniu ściśle karnym 59. Pogląd ten miał jednak znaczenie tylko jako votum w okresie prac nad reforma prawa karnego, albowiem w Kośçele utrzymane zostało prawo karne, którego nie można ignorować.

W rozważaniach na temat ekskomuniki nasuwa się pytanie dotyczące charakteru przymusu w karze ekskomuniki oraz jej skuteczności pastoralnej, czyli wychowawczej - czy kara ta zmierza jedynie do poprawy przestępcy w znaczeniu społecznym, czy zmusza go także do nawrócenia w sensie teologicznym?

W myśl kan. 1312 eksikomunika jest cenzurą, czyli karą leczniczą (poena medicinalis), stąd tė̇ zasadniczy jej cel wyznaczony przez prawodaweę stanowi poprawa przestępcy. Ponadto charakter leczniczy lub poprawczy cenzur wyraża się w konieczności uporu po stronie sprawcy do ich wymierzenia (kan. 134.7 \& 1) oraz czasem ich trwania (kan. 1358 § 1).

Kara ekskomuniki może byé wymierzona jedynie przestępcy, który pomimo upomnienia kanonicznego nadal trwa w uporze, tzn. wykazuje pogardę ustawy i sankcji karnej. Istotnymi elementami uporu ze strony sprawcy są jego zła wola oraz znajomość ustawy i grożącej sankcji karnej w postaci ekskomuniki 60. Należy zauważyć, że upór ten nie zmienia teologicznej natury grzechu ani tė̇ $z$ zasady nie jest elementem konstytutywnym przestępstwa ${ }^{61}$. Zgodnie $z$ kan. $1358 \S 1$ ekskomunika wiąże ukaranego tak dlugo, jak długo istnieje jego upór, inaczej mówiąc - czas nbowiązywania cenzury zależy od woli sprawcy. Toteż zasadiniczy cel ekskomuniki stanowi złamanie uporu przestępcy, czyli doprowadzenie go do poprawy.

Przejawem odstąpienia od uporu w myśl kan. $1347 \S 2$ jest rzeczywisty żal za popełnione przestępsitwo (a contumacia recessisse dicendus est reus, quem delicti vere paenituenit). Odstapienie od uporu to akt wolnej woli zmierzajacy do autentycznej poprawy. W sensie teologicznym poprawa oznacza nawrócenie wiernego, który pragnie pojednać się z Bogiem i z Kościolem, co zwyczajnie dokonuje się $\mathrm{w}$ sakramencie pokuty. Jeżeli prawodawca domaga się od ekskomunikowanego tak radykalnej zmiany woli, to tym samym dąży do nawrócenia w znaczeniu teologicznym. De-

\footnotetext{
$59 \mathrm{~V}$. De Paolis, Aspectus theologici et iuridici in systemate poenali canonico, Periodica 75 (1986), s. 225.

${ }_{60}$ M. M y r cha, Prawo karne. Komentarz do piatej księgi Kodeksu Prawa Kanonicznego, t. II, cz. 1, Przepisy ogólne, Warszawa 1950, s. $467-470$.

${ }^{\circ 1}$ L. Geros a, Ist die Exkommunikation eine Strafe? Archiv für katholisches Kirchenrecht 154 (1985), s. 99-100.
} 
cyzja w tej mierze zależy jednak tylko i wyłącznie od woli ukaranego 62 .

Istota ekskomuniki polega na pozbawieniu wspólnych wszystkim wiernym dóbr, którymi Kościól może dysponować 63. Dla wiernych szczególnie bolesnym następstwem tej kary jest zakaz przyjmowania wszystkich sakramentów (kan. 1331 § 1) ${ }^{4}$. W tej sytuacji skutki ekskomuniki skłaniają winowajce do postawienia pytania o spójność jego postawy z posłannictwem Kościola, pytania dotyczącego jego wlasnego nawrócenia. Tym sposobem Kośció pragnie wpłynąc na wolę wiernego, aby podjąl on wolny akt nawrócenia. Kara ta z całą pewnością nie jest bezpośrednim środkiem wykanawczym, który wprost wymusza poprawę, gdyż zależy ona od dobrej woli winnego ${ }^{65}$. Ekskomunika przymusza natomiast sprawcę do poprawy $w$ sposób pośredni — jeżeli chce on ponownie otrzymać utracone prawa we wspólnocie wiernych zwłaszcza prawo do udziału w życiu sakramentalnym Kościoła. Chęć korzystania z łask sakramentalnych jakso skłaniająca do odstapienia od uporu jest wyrazem rzeczywistego nawrócenia się przestępcy i grzesznika. Takie nawrócenie spełnia podstawowy wymóg konieczny do otrzymania absolucji od kary oraz warunki, jakie w myśl kan. 987 przewidziane są do otrzymania absolucji sakramentalnej $z$ popelnionych grzechów. Z tego punktu widzenia uznać należy, że ekskomunika jest skutecznym środkiem duszpasterskim prowadzącym do uświęcenia wiernych.

Zgodnie $z$ postanowieniem kan. $1347 \S 2$ zaniechanie uporu opiera się nie tylko na żalu winnego i jego poprawie. Poza tym podstawowym warunkiem sprawca zobowiązany jest ponadto do naprawienia szkody i zgorszenia lub do złożenia poważnej obietnics, że to uczyni. Z chwila ustania uporu ekskomunikowany nie jest automatycznie uwolniony od kary, nabywa on jedynie prawo do uzyskanda absolucji, co również stanowi warunek niezbędny do jej udzielenia 66 .

Wydaje się jednak, że nie można przeceniać znaczenia ekskomuniki, gdy chodzi o jej skuteczność duszpastersko-wychowawcza. Poprawa ukaranego w postaci porzucenia przez niego uporu wcale bowiem nie musi być równoznaczna z rzeczywistym nawróceniem sie w sensie teologicznym. Cdstąpienie od uporu może stanowić tylko zewnętrzne podporządkowanie się wymogom prawa w celu

\footnotetext{
62 A. B ox r a s, dz. cyt., s. 287.

$68 \mathrm{~V}$. D e $\mathrm{P}$ a.olis, Aspectus theologici et iuridici..., s. 248.

64 Skutki ekskomuniki nie sa automatycznym wynkiem popelnionego grzechu, lecz są następstwem wymierzonej kary za dokonane przestepstwo; V. D e $\mathrm{Pa}$ alis, Aspectus theologici et iuridici..., s. $247-248$.

65 A. Borras, dz. cyt., s. 287, 302-303.

${ }_{66}$ M. M y r h ha, Prawo karne, s. $137,537-579$.
} 
uzyskania absolucji od kary. Toteż inne warunki musi spełniać ekskomunikowany, aby otrzymać uwolnienie od kary, inne zaś konieczne są do uzyskania absolucji sakramentalnej. Zachodzi też istotna różnica pomiędzy absolucją $z$ cenzur a zwolnieniem $z$ grzechów, która uwidacznia się w celu, do jakiego zmierzają obie te instytucje. Istotę i cel absolucji sakramentalnej stanowi bowiem pojednanie grzesznika z Bogiem i z Kościolem, co uwarunkowane jest poprawą penitenta, czyli jego wewnętrzną przemianą określaną pojęciem metanoia. Absolucja natomiast $z$ cenzur zmierza do pojednania z Kościołem pod warunkiem, że sprawca odstąił do uporu, czyli poprawił się $w$ tym zakresie, jaki stanowił podstawe wymierzenia kary. $\mathrm{Z}$ tego względu możliwe jest udzielenie absolucji z jednej ekskomuniki bez zwolnienia $z$ innej. Odmiennie przedsta'wia się rozgrzeszenie $w$ sakramencie pokuty: penitent nie może być rozgrzeszony $z$ jednego grzechu, pozostając jednocześnie $w$ innych grzechach ${ }^{67}$. Wynika $z$ tego, że zachodzi różnica między nawróceniem penitenta a nawróceniem ekskomunikowanego. Upoważnia to do stwierdzenta, że ekskomunika w hierarchii środków pedagogicznych w Kościele nie zagmuje zbyt wysokiego miejsca 68 .

Zdaniem niektórych kanonistów 69 kara ekskomuniki, chociaż zmierza do poprawy przestępcy, może być również wymierzana tym sprawcom, co do których nie ma uzasadnionej nadziei, że się poprawią. Jeżeli pierwszorzędny cel ekskomuniki w postaci poprawy jest nieosiągalny, pozostają cele drugorzędne tej kary, którymi są odplata za popelnione bezprawnie kryminalne (pomszczenie przestępstwa) oraz odstraszenie innych wiernych przed tego rodzaju czynami, a więc prewencja generalna. W tej sytuacji pomimo upatrywania $w$ ekskomunice celów drugorzędnych nadal pozostaje ona karą poprawczą; w Kościele bowiem nigdy nie można wątpić w poprawę i nawrócenie grzeszącego brata. Postawa zwątpienia w nawrócenie bliźniego sprzeczna jest $z$ duchem Ewangelii i z postawą Chrystusa wobec grzeszników, toteż Kościół wymierzając ekskomunike - zawsze ma nadzieję na poprawę przestępcy, tej poprawy życzy mu i jej oczekuje 70. W ostateczności, jeżeli winowajca nie chee prawdziwie żałować za popełmione przestepstwo i nie ma zamiaru poprawienia się, ekskomunika przestaje być dla niego „karą". Całkowita obojętność sprawcy wobec Kościoła i swojego nawrócenia powoduje, iż wymie-

${ }^{67}$ Tamíe, s. $564-565$.

${ }^{88}$ R. Sobań ski, O niektórych problemach prawa karnego, s. 17 .

69 R. Salucci, Il dirito penale secondo il Codice di diritio canonico, t. II, Subiaco 1930, s. 180; F. Cappe 110 , Tractatus canonico- moralis de censuris iuxta Codicem Iuris Canonici, ed. 4, Romae-Taurini 1950 , s. 4, n. 1; M. IM y r c h a, Prawo karne, s. 137-138.

70 A. B orrats, dz. cyt., s. 292. 
rzona kara - z jego punktu widzenia - ogranicza się do deklaracji stanu faktycznego o niezgodności jego życia ze wspólnotą kościelną, z którą w rzeczywistości nie chce utrzymywać zasadniczych więzów 71. Z punktu widzenia Kościoła $w$ tej sytuacji ekskomunika nadal jednak pozostaje karą poprawczą, albowiem Kościól zawsze liczy na nawrócenie przestępcy, nie rezygnuje $z$ jego poprawy. Skuteczność więc ekskomuniki nie jest i nie może być mierzona analogicznie do skuteczności kary $w$ prawie państwowym.

Reasumując należy stwierdzić, ze kara ekskomuniki nie jest w stanie wymusić poprawy, jeżeli ukarany sam nie zechce się nawiócić. Kara ta przeciwstawia się woli sprawcy zaangażowanej w zło i pośrednio skłania tę wolę do podjęcia wolnego aktu poprawy. Zmierza do tego, aby przestępca nawrócil się i wszedl na drogę pełnej inkorporacji do Kościola, co ostatecznie dokonuje się $w$ sakramencie pokuty. Toteż przez ekskomunikę Kościół dą$\dot{z y}$ nie tylko do poprawy społecznej, ale również do nawrócenia w sensie teologicznym. Dążenie to nie może być jednak identyfikowane ze skutecznością w postaci autentycznego nawrócenia. Do uzyskania absolucji z cenzury wystarczy bowiem - jak to wyżej wykazano - zewnętrzne podporządkowanie się wymogom prawa. Wreszcie ekskomunika, ponieważ bezpośrednio nie wymuisza nawrócenia, nie może być uważana za środek przymusu sprzecznj z zasadą wolności religii 72.

W świetle tegio, co datychczas powiedziano, nasuwa się pytanie - czy poprawie przestepcy lepiej służy ekskomunika zaproponowana w Projekcie z 1973 r., czy też w obecnie obowiązującym prawie?

Zarówno według Projektu z 1973 r., jak i zgodnie z Kodeksem z 1983 r. ekskomunika jest cenzurą, czyli karą leczniczą, która zmierza do poprawy przestępcy. Realizacje tego celu oba dokumenty ujmują jednak różnie. Różnica ta wynika przede wszystkim $\mathrm{z}$ odmiemnych skutków eksikomunikji w zakresie korizystania z sakramentów świętych. W myśl Projektu z 1973 r. kara ekskomuniki nie stanowi przeszkody $w$ przystąpieniu do sakramentu pokuty. Toteż ekskomunikowany, jeżeli się nawraca, zawsze ma prawo do pojednamia z Bogiem i z Kościolem, które dokonuje się przez absolucję sakramentalną. Jego rozgrzeszenie zależy wylącznie od speknionych warunków moralnych, tzn. od poprawy w sensie teologicznym. Ukarany ma zawsze wolny przystęp do sakramentu pokuty.

Ekskơmunika w Projekicie z 1973 r. wyraża więc szacunek wobec sumienia sprawcy. Nie wywiera ona żadnego przymusu do

71 Tamże, s. $302-303$.

7) Tamie, s. 303 . 
nawrócenia w znaczeniu teologicznym, troskę o poprawe moralną pozostawiając innym środkom sỉuzącym temu celowi. Ponieważ Projekt nie chce nawracać przy pomocy kary ${ }^{73}$, cel ekskomuniki stanowi tu wyłącznie poprawa przestępcy $w$ znaczeniu spolecznym. Jej przejawem w myśl kan. 31 \$ 2 jest szczere porzucenie przestepnej woli, a ponadto naprawienie szkody i zgorszenia lub poważna obietmica uczynienia tego. Ten pierwszy warunek odstapienia od uporu świadczący o poprawie musi być zawsze spelniony, gdy przestępca i grzesznik przystepuje do sakramentu pokuty. $Z$ tej racji po otrzymaniu absolucji sakramentalnej ekskomunika zatraca swój poprawczy charakter i wyraża tylko cel ekspiacyjny. Tym samym Projekt z 1973 r. zaciera różnice pomiędzy karami poprawczymi (cenzurami) i ekspiacyjnymi. Ekskomunikowany, chcąc otrzymać absolucje sakramentalną, winien tak jak każdy grzesznik - okazać swoja poprawę i nawrócenie w znaczeniu moralnym (teologicznym). Takie nawrócenie w Kościele nie może być obojętne dla zakiresu zewnętrznego. Jednakże mimo rzeczywistej poprawy na sprawcy ciązy nadal obowiązek przestrzegania kary. Skutki ekskomuniki nie służą wówczas jego poprawie, ponieważ już się ona dokonała. Ekskomunika może micć wtedy inne cele, lecz nie utożsamiają się one $z$ jej celem pierwszorzędnym ${ }^{74}$, którym jest poprawa. Należy również zauważyć, iż w przypadku przestępstw tajnych, pomimo otrzymanego rozgrzeszenia i spelnienia waruników świadczących o porzuceniu uporu, sprawca, aby móc otrzymać zwolnienie z kary, musi odnieść się do wladzy zakresu zewnętrznego 75. Wynika z tego, że Projekt z 1973 r. w przypadku ekskomuniki na plan pierwszy wysuwa ekspiacyjny $\mathrm{i}$ odwetowy cel tej kary, jej cel poprawczy natomiast schodzi na dalszy plan i ogranicza sie wylacznie do poprawy w znaczeniu spolecznym.

W świetle tego, co wyżej powiedziano, należy stwierdzić, że poprawie przestępcy lepiej siuzy ekskomunika w ujęciu Kodeksu z 1983 r. niż Projektu z 1973 r. W obowiązującym prawie zasadniczym i pierwszorzęnym celem omawianej kary jest poprawa, do której ustawodawca zmierza przy pomocy drastycznych środków - odimawiając ekskomunikowanemu prawa przyjmowania wszystkich sakramentów, w tym także sakramentu pokuty. Chociaz nawrócenie ekskomunikowanego zależy od jego wolnej woli, to jednak ekskomunika zmierza do poprawy nie tylko $w$ znaczeniu społecznym, ale także w sensie teologicznym.

75 V. De Paolis, De recognoscendo iure poenali canonico, s. 67; Tenzie, Totum ius poenale ad externum..., s. 301, 309. 330 .

${ }^{74}$ F. Coccopalmerio, De natura iuris poenalis Ecclesiae, s.

${ }_{75} \mathrm{Na}$ praktyczne trudności z tym zwiąane wskazuje R. Sobański, $\mathrm{i}$ niektórych problemach kościelnego prawa karnego, s. 175.

Io - Prawo Kanoniczne 


\section{Ekskomunika a sakrament pokuty}

Jak już powiedziano, o poprawie przestępcy-grzeszmika decyduje jego pojednanie $z$ Bogiem i Kościołem, które w sposób zwyczajny dokonuje się przez absolucję sakramentaliną $w$ czasie spowiedzi 76. Każdy grzesznik, jeżeli pokutuje i nawraca się, ma prawo do pojednania $z$ Bogiem i Kościolem w sakramencie pokuty, czyli może otrzymać odpuszczenie grzechów po chrzcie popełnionych (kan. 987). Prawa tego pozbawiony jest natomiast przestępca ukarany ekskomunika, albowiem kara ta - zgodnie $\mathrm{z}$ kan. $1331 \S 1,2^{\circ}$ - zabrania dostępu do wszystkich sakramentów, nie wyłączając sakramentu pokuty. Ekskomunika pozbawia więc dóbr nadprzyrodzonych koniecznych do zbawienia. Z pastoralnego punktu widzenia dochodzi tu do konfliktu pomiędzy uprawnieniem wiernego do sakramentu pokuty a pozbawieniem go tego prawa - co jest skutkiem kary - mimo że ekskomunikowany spełnia inne warunki konieczne do otrzymania absolucji sakramentalnej. Nie może on bowiem otrzymać rozgrzeszenia, dopóki nie zostanie uwolniony od kary - odpuszczenie grzechów uzależnione jest więc od uprzedniego uwolnienia ad ekskomuniki.

$Z$ postanowien prawa karnego $w$ Kodeksie z 1983 r. jasno wynika, że zwalnianie $\mathrm{z}$ kar $\mathrm{w}$ Kościele należy do władzy rządzenia wykonywanej w zakresie zewnętrznym. Sa jednak racje pastoralne, które skłoniły ustawodawce, aby od zasady tej - zwlaszcza gdy chodizi o kary poprawcze - uczynil pewne odstępstwa 77. Innymi słowy - względy duszpasterskie przemówiły za powiązaniem prawa kamego $z$ sakramentem pokuty $w$ tym, co dotyczy kwestii zwalniania $z$ kar kościelnych. Zasada prawna, że zwalnianie $z$ kar dokonuje się $w$ zakresie zewnętrznym, nie może być tak bezwzględnie aplikowana, ażeby ekskomunikowany żałujący swego czynu i pokutujący nie mógł uzyskać prawa dostępu do ścodków nadprzyrodzonych. Totez w Kodeksie z $1983 \mathrm{r}$. prawodawca, kierując się racjami duszpasterskimi, przewidzial normy, które wyposażają spowiedników we władzę uwalniania od cenzur latae sententiae (zwłaszcza ekskomuniki i interdyktu), gdy kary nie zostaly jeszcze deklarowane w postępowaniu sądowym lub administracyjnym. Przepisy prawne $z$ jednej strony wyrażają troskę Kościoła o zbawienie dusz i elsskomunikowanemu przed wyrokiem wyjaśniającym dają możliwość korzystania $z$ dóbr nadprzyrodzonych, z drugiej zaś - prawodawca stara się, aby ekskomunika nie utraciła charakteru kary, i dąży do utrzymanja zasady, że zwalnianie $z$ kar dokonuje się $w$ zakresie zewnętrznym 78 .

76 Kan. 960.

77 V. De Paolis, De sanctionibus in Ecclesia, s. 98.

${ }_{68}$ J. Syryjczyk, Sakrament pokuty $w$ karnym prawie kanonicz- 
Zwalnianie $z$ kar $w$ sakramencie pokuty prowadzi do powstawania konflikitów pomiędzy zakresem zewnętrznym i wewnętrznym, co jest zjawiskiem bardzo niekorzystnym $w$ działalności duszpasterskiej Kościoła. Powstaja więc pytania: jak w obecnym Kodeksie ksztaltuje się powiązanie ekskomuniki z sakramentem pokuty oraz jakie sa konselkwencje pastoralne zwalniamia $\mathrm{z}$ kar $\mathrm{w}$ zakresie sakramentalnym?

W Kodeksie z 1983 r. prawodawca udzielił na sposób stały niektórym spowiednikom władzy uwalniania od kar w sakramencie pokuty, z czego moga korzystać w sytuacjach lub wypadkach zwyczajnych. Oprócz tego każdy spowiednik posiada władzę uwalniania od kar $w$ wypadkach nadzwyczajnych, tj. w niebezpieczeństwie śmierci 78 i gdy zachodzi wypadek nagly (casus urgens) ${ }^{80}$.

Stałą władzę uwalniania od kar $\mathrm{w}$ sakramencie pokuty $\mathrm{w}$ różnym zakresie posiadają: każdy biskup (kan. 1355 § 2), kanonik penitencjarz kościola katedralnego i kolegiackiego (kan. $508 \S 1$ ), kapelani w szpitalach, więzieniach oraz kapelani podróżujących na morzu (kan. 566 \& 2). Z władzy zwalniania $z$ kar w zakresie sakramentalnym mogą korzystać także ondynariusze, którzy zwalniają $\mathrm{z}$ tychże kar $\mathrm{w}$ zaksresie zewnętrznym (kan. 1355-1356). Poza tymi osobami inni spowiednicy posiadają władzę uwalniania od kar, gdy do tego zostali delegowani (zgodnie z kan. 137 § 1) przez ordynariuszy, o których mowa w kan. 1355-1356.

Zwalnianie $\mathrm{z}$ kar $\mathrm{w}$ sakramencie pokuty przez wymienionych spowiedników dotyczy najcześciej cenzur, jeżeli kary te nie zostały jeszcze deklarowane i nie są zastrzeżone Stolicy Apostolskiej. Władza spowiedników, o których mowa, rozciąga się nie tylko na kary za przestępstwa tajne, ale dotyczy także przestępstw faktycznie notorycznych. Warunkiem przez prawo bezwzględnie wymaganym jest bowiem, aby kara latae sententiae nie zostala deklarowana. Zwolniemie $\mathrm{z}$ nich $\mathrm{w}$ zakresie sakramentalnym ma ten sam charakter co absolucja udzielona $w$ zakresie zewnętrznyrn. Od spowiedników, którzy w zwyczajnych wypadkach uwalniają od kar, nie wymaga się, aby nakładali na penitentów obowiązek odniesienia się do kompetentnego przełożonego po mandaty ani też po uwolnienie od kary w zakresie zewnętrznym. Nawet penitent zwolniony $\mathrm{z}$ ekskomuniki (lub interdyktu) $\mathrm{w}$ wypadku nagłym zwraca się do władzy zakresu zewnętrznego po odpowiednie zalecenia, lecz nie po uwolnienie od kary, gdyż został $z$ niej zwolniony $w$ sakramencie pokuty. Wynika $z$ tego, że zwolniony $\mathrm{z}$ kar $\mathrm{w}$ zakresie wewnętrznym winien za takiego

nym, w: Duszpasterstwo w świetle nowego Kodeksu Prawa Kanonicznego, s. 283.

79 Kan. 976.

$80 \mathrm{Kan} .1357 \S 1$. 
uważać się również w zakresie zewnętrznym. Nie nastręcza to żadnych trudności, gdy np. ekskomunika była i jest tajna, problem staje się jednak bardziej zlożony, kiedy kara ma charakter publiczny, a także gdy była tajna i po jakimśs czasie wyszło na jaw jej zaciągnięcie. Czyż wówczas sprawca może być uważany przez władzę zakresu zewnętrznego za ekskomunikowanego? Jeżeli tak, to ponownie musiałby on starać się o zwolnienie od kary, z której faktycznie został zwolniony. Jedynym rozwiązaniem dla oskarżonego pozostaje więc prizyznać się do popełnionego przestępstwa i udowodnić fakt otrzymania absolucji w zakresie sakramentalnym. Wydaje się, że w pewnych wypadkach takie przyznanie się do przestępstwa czyni iluzorycznym przepis kan. 1728 $\S 2$, który podkreśla, że oskarżony nie ma obowiązku przyznawać się do przestępsíwa. Trudności nastręcza także udowadnienie absolucji atrzymanej w zalkresie wewnętrznym. Zgodnie z kan. 1550 $\S 2$, który stoi na straży tajemnicy spowiedzi, kapłanowi nie wolno ujawnić niczego, co poznał w sakramencie, chociażby penitent prosił o ujawnienie tego.

To wszystko tworzy dla oskarżonego wielce niekorzystną sytuację. Czy wówczas - jak chcą niektórzy autorzy 81 - sporwiednik może przyjść z pomocą penitentowi, wystawiając zaświadczenie o udzielonej absolucji? Odpowiedź twierdząca rodzi pytanie o granice tajemnicy sakramentalnej spowiedzi. Jeżeli zaświadczenie o otrzymanej w sakramencie pokuty absolucji może być środkiem dowodowym, to spowiednik powinien takie zaświadczenia wydawać zawsze bez względu na to, czy przestępstwo jest notoryczne czy tajne, gdyż to ostatnie zawsze może stać się przestępstwem publicznym. Z kolei dla sędziego zaświadczenie takie jest tylko dowodem poszlakowym i nie musi wystarczająco przekonywać go o twierdzeniach oskarżonego ${ }^{82}$. Przekonanie sędziego może być inne od stanu faktycznego tym bardziej wtedy, gdy oskarżony twierdzi, że zostal uwolniony od kary i nadal rażąco narusiza porządek prawny (chociaż nie wchodzi jeszcze w kolizję $z$ prawem karnym).

W świetle powyższego należy stwierdzić, że powiązanie instytucji zwalniania $z$ kar $z$ sakramentem pokuty nie wprowadza doskonałej harmonii pomiędzy zakresem zewnętrznym i wewnętrznym, co stanowiło ideę przewodnią odnowy kościelnego prawa karnego i sakramentalmego.

Innym pastoralnie niekorzystnym skutkiem zwalniania $\mathrm{z}$ ekskomuniki w sakramencie pokuty jest możliwość powstawania zgor-

81 F. Roberti, De delictis et poenis, vol. $I$, pars $I I$, Romae 1945, s. $353-354$; M. M y r c h a, Prawo karne, s. $597-598$.

82 Por. Kan. 1586. 
Szenia wśród wiernych 83. Mogą się oni gorszyć, jeżeli są świadomi zaciągniętej przez sprawcę ekskomuniki, zaś nic nie wiedzą o udzielonej absolucji $i$ widzą, jak - ich zdaniem - ekskomunikowany przystępuje np. do Komunii św. Niebezpieczeństwo takie powstaje zwlaszcza wtedy, gdy ekskomunika jest publiczna lub notoryezna. Poprzedni Kodeks w kan. 2251 wyrażał zasadę, w myśl której jeżeli absolucja została udzielona w zakresie wewnętrznym, to uwolniony od cenzury mógł za takiego się uważać również w zakresie zewnętranym, odsuwając niebezpieczeństwo zgorszenia. Uwolniony od kary był więc zobowiązany do usunięcia zgorszenia i niedopuszczenia do jego powstania, toteż musiał unikać aktów publicznych, $z$ których moglo powstawać zgorszenie, zanim nie udowodnił uzyskania absolucji. $Z$ jednej strony nie wydaje się, aby powyższa reguła obowiązywała nadal, albowiem Kodeks z 1983 r. zniósł przepis kan. 2251 Kodeksu z 1917 r. Z drugiej jednak strony należy sądzić, iż $\mathrm{w}$ dalszym ciągu obowiązuje zasada, że zwolniony $\mathrm{z}$ ekskomuniki notorycznej $\mathrm{w}$ sakramencie pokuty $w$ zakresie zewnętrznym ma zachowywać się tak, jakby absolucji nie otrzymal 84. Pogląd ten znajduje swoje uzasadnienie w tym, że zwolnionemu $z$ kary nie wolno dawać zgorszenia. Warunkiem udzielenia absolucji $\mathrm{z}$ ekskomuniki jest między innymi obowiązek naprawienia zgorszenia lub poważna obietnica uczynienia tego. Jeżeli więc zwolniony $z$ ekskomuniki w sakramencie pokuty podejmuje czynności wywołujące zgorszenie, tym samym nie wypełnia obowiązku, który stamowił podstawę udzielonej mu absolucji.

Nie mniej pastoralnie trudne problemy powstają w związku ze zwolnianiem $z$ cenzur $w$ sakramencie pokuty $w$ wypadku nagłym (casus urgens). W myśl kan. $1357 \S 1$ zachodzi on wtedy, gdy penitentowi ze względu na zaciągniętą karę ekskomuniki lub interdyktu (latae sententiae), która nie została jeszcze deklarowana, trudno jest pozostawać w grzechu ciężkim przez czas konieczny do zniesienia cenzury przez kompetentnego przełożonego. Prawodawca, kierując się dobrem duchowym przestępcy, któremu kara zabrania przyjmowania sakramentów świętych, daje mu możliwość pojednania się $\mathrm{z}$ Bogiem i Kościolem w sakramencie pokuty bez konieczności uciekania się - celem uwolnienia się od kary - do władzy zakresu zewnętnznego. Odpuszczenie grzechów, gdy kara zabrania przystępowania do sakramentu pokuty, domaga się uprzedniego uwolnienia od kary, co $\mathrm{w}$ wypadku naglącym równocześnie dokonuje się w zakresie wewnętrznym, czyli sakramentalnym.

${ }^{83}$ M. M y r cha, Prawo karne, s. 596.

$84 \mathrm{~V}$. D e Paolis, Coordinatio inter forum internum et externum in novo iure poenali canonico, Periodica 72 (1983), s. 428-430. 
Spowiednik, udzielając absolucji w nagłym wypadku, winien małożyć na penitenta obowiązek odniesienia się $w$ przeciągu miesiąca - pod kara nawrotu cenzury - do kompetentnego przełożonego lub kapłana obdarzonego władzą po odpowiednie mandaty i zastosować się do jego zaleceń. Odniesienie się do właściwego przełożonego (lub kapłana) może dokonać się także przez spowiednika bez podania nazwiska penitenta. Spowiednik, który uwalnia od ekskomuniki (bądź interdyktu), ma obowiązek nałożenia pokuty jako elementu czyniącego zadość popełnionym grzechom i będącego tymozasową odpłaita za dokonane przestępstwo, dopóki przełoziony zakresu zewnętrznego (lub kapłan pisiadajacy odpowiednia władzę) nie nałoży stosownych mandatów (kan. 1357 § 2). Naprawienie zgorszenia i szkody może być koniecznym warunkiem otrzymania absolucji od kary i grzechów (por. kan. 1358). Wydaje się, że wymogi te są niezbędne zwłaszcza wtedy, gdy zaciągnięta cenzura jest notoryczna. Uwolnienie od cenzury notorycznej może bowiem być udzielone $\mathrm{w}$ wypadku nagłym pod warunkiem, że kara ta nie została jeszcze deklarowana 85.

Zwolnienie $z$ ekskomuniki $w$ wypadku nagłym nie rozwiązuje całkowicie problemów sprawcy. Ciąży bowiem na nim obowiązek odwołania się w przeciągu miesiąca - pod groźbą tej samej kary - do kompetentnego przełożonego lub kapłana obdarzonego odpowiednią władzą po mandaty. Pomimo że w wypełnieniu powyższego obowiz̨zku penitent może być wyręczony przez spowiednika, to jednak $z$ wielu względów nie zawsze będzie on mógł tego dokonać. Poza tym zarówno spowiednik, jak i penitent nie zawsze znają kapłanów, któnzy otrzymali odpowiednią wladzę i są $w$ stanie zaradzić powyższym trudnościom. Stąd téz jedynym rozwiązaniem dla penitenta pozostaje zwrócić się do przelożonego w zakresie zewmętrznym. Jest to bardzo trudny obowiązek dla osoby, która zaciągnęla karę ekskomuniki szczególnie wtedy, gdy przestępstwo i kara są tajne. Zgodnie z tym np. kobieta, która na skutek przerwania ciąży zaciągnęła ekskomunikę latae sententiae, pomimo otrzymania $w$ sakramencie pokuty absolucji zobowiązana jest do ujawnienia tego faktu $w$ zakresie zewnętrznym ${ }^{86}$. Oprócz oporów natury psychicznej przed ujawnieniem swego przestępstwa wobec władzy w zakresie zewnętrznym penitent obawria się także możliwości zniesławienia. Prawodawca, licząc się z niebezpieczeństwem zniesławienia sprawcy, przy zwalnianiu $z$ kar $w$ kan. 1361 \& 3 poleca, aby prośba o zwolnienie z kary lub samo zwolnienie mie były rozgłaszane. Można twierdzić, że dotyozy to także zwracania się po mandaty. Jednakże powyższa zasada nie

85 Tenże, Quaestiones miscellaneae, Perioidica 73 (1984), s. 480.

86 R. Sobański, O niektórych problemach kościelnego prawa karnego, s. 175 . 
może zagwarantować, że zwracający się po nie w zakresie zewnętrznym nie narazi się na zniesławienie. Ponadto odniesienie się po zalecenia do władzy zakresu zewnętrznego jest równoznaczne z przyznaniem się do przestępstwa, chociaż sprawca nie został o nie oskarzony.

Poprzedni Kodeks z 1917 r. w kan. 2254 \& 3 przewidywal możliwość uwolnienia od cenzur latae sententiae $\mathrm{w}$ sakramencie pokuty $z$ jednoczesnym nałożeniem mandatów w wypadku nadzwyczajnym, czyli wtedy, gdy odniesienie się penitenta do kompetentnego przełożonego było moralnie niemożliwe. Obecnie spowiednik nie może zwolnić penitenta $z$ obowiązku zwrócenia się po mandaty ani też nie może nalożyć ich sam, ponieważ uchylony został przepis kan. $2254 \S 3 \mathrm{KPK}$ z 1917 r. Nie ulega wątpliwości, że równiez $w$ obecnej rzeczywistości Kościoła wniesienie rekursu niejednokrotnie będzie moralnie lub fizyoznie niemożliwe, szczególnie gdy chodzi o odwolanie się do Stolicy Apostolskiej z bardzo odległych regionów świata 87.

Zgodnie z kan. $1357 \S 2$ KPK z 1983 r. niewypełnienie powyzszego obowiązku w przeciagu miesiaca od otrzymanej absolucji zagrożone jest sankcją karną w postaci nawrotu cenzury. Należy sądzić, że penitent na pewno nie zaciągnie cenzury, jeżeli odwołanie sie po mandaty będzie moralnie niemożliwe. Twierdzenie to uzasadnia zasada prawna, wedlug której ustawy kościelne nie obowiązują w wypadku wielkiej niedogodności - nemo potest ad impossibile obligari 88 . Wobec tego powstaje pytanie: czy w przypadku niemożliwości moralnej powyższy obowiązek wygasa po upływie miesiąca, czy też przediuzza się aż do czasu ustania przeszkody? Wydaje się, że problem ten może mieć dwojakie rozwiązanie.

W myśl jierwszego, jeżeli z powodu przeszkody nie można wnieść odwolania, obowiązek wykonania tegoż pozostaje nadal aż do czasu, gdy odniesienie będzie możliwe. Inaczej mówiąc obowiązek ten jest przewidziany ad urgendam non ad finiendam obligationem 89. Rozwiązaniu temu sprzeciwia się jednak ścisła

${ }_{87} \mathrm{Z}$ trudności odniesienia się do Stolicy Apostolskiej zdawał sobie sprawę zespól opracowujący nowe prawo karne. Dowodem na to jest fakt, że w Projekcie Kodeksu z 1980 r. ekskomunika za przestępstrwo profanacji Eucharystii nie była zastrzeżona Stolicy Apostolskiej (kan. 1319), czego domagali się niektórzy konsultorzy. Wyjaśniono wótvczas, że przyjęty system prawa karnego, a zwlaszcza niemożność zwolnienia $z$ kaưy zastrzeżonej $w$ wypadku nagłym (kan. 1309 \& 1), stwarza olbrzymie trudności w uwolnieniu się od takiej ekskomuniki; Communicationes 15 (1984) 48.

88 V. De Paolis, Coordinatio inter forum internum et externum..., s. 431 ; $\mathrm{P} . \mathrm{Huizing}$, De iudicio poenali in foro poenitentiali, s. 271.

${ }_{89}$ F. R o berti, dz. cyt., vol. I, pars II, s. $365 ; \mathrm{M}$. M y r ha, Prawo karne, s. 658 . 
interpretacja prawa kamnego (kan. 18) oraz zasada, iż w watpliwości prawnej ustawy kościelne nie obowiązują (kan. 14) 90. Ponadito kan. $1357 \S 2$ mówi o okresie jednego miesiąca jako terminie ściśle określonym (prekluzyjnym), którego przekroczenie w sytuacji zwyczajnej powoduje nawrót cenzury.

Według drugiego rozwiązania obowiązek zwrócenia się po mandaty w przypadku niemożliwości moralnej całkowicie ustaje po upływie miesiąca. Uzasadnia to fakt, że prawodawca nie uzależnia tego obowiązku od jakichkolwiek okoliczności, które prizedkużałyby termin zwrócenia się po mandaty 91 , totez czas, o którym mowa W kan. $1357 \S 2$, zostal określony ad finiendam obligationem ${ }^{\mathbf{2}}$.

$\mathrm{Z}$ teoretycznego punktu widzenia to drugie rozwiązanie wydaje się bardziej uzasadnione, chociaz $z$ kolei $z$ duszpasterskiego punktu widzenia jest ono trudniejsze do przyjęcia. Sytuacja bowiem, gdy zachodzi nadzwyczajny wypadek, bylaby korzystniejsza (uwalniałaby go od mandatów) anizeli penitenta, który nie znajduje się w takiej okoliczności, co uznać naleźy za nie bardzo słuszne.

W świetle powyższego nasuwa się wniosek, że prawna regulacja wypadku nagłego w Kodeksie z $1983 r$. jest znacznym obostrzeniem dyscypliny karnej $w$ parównaniu $z$ ía, jaka $w$ tej materii wyrazil poprzedni Kodeks z 1917 r. Nie zachęca ona tez wiernych do sakramentu pokuty, w którym można otrzymac absolucję od cenzur latae sententiae, albowiem otrzymana absolucja nie rozwiazuje cefinitywnie wszystkich problemów związanych ze zwalnianiem z kar. Pomimo że zwalnianie $z$ cenzur $w$ sakramencie pokuty w nagkym wypadku podyktowane jest dobrem duchowym przestępcy, to powstające trudności natury zarówno teoretycznej, jak i praktycznej wskazują na niewielka przydatność tej instytucji w praktyce duszpasterskiej.

Takie a nie inne ujęcie wypadku nargłego w Kodeksie z 1983 r. jest wynikiem zbyt sztywnej realizacji zasady, że zwalnianie $z$ kar dokonuje się $w$ zakresie zewnętrznym. Zasada ta zmusila zespół opracowujący nowe prawo karne do przeredagowania normy dotyczącej wypadku naglego, która ustalono $w$ dniu 4 czerwca 1977 r. Zaproponowano witedy, że w nagłym wypadku spowiednik może bez odsyłania penitenta do kompetentnego przełozonego po odpowiednie zalecenia (mandaty) zwalniać $z$ ekskomuniki i interdyktu latae sententiae, gdy cenzury te nie są jeszcze orze-

$90 \mathrm{~V}$. De Paolis, Coordinatio inter forum internum et externum..., s. 431 .

91 J. Syryjczyk, Sakrament pokuty $w$ karnym prawie kanonicznym, s. 284.

${ }_{92}$ V. De Paolis, De sanctionibus in Ecclesia, s. 106. 
czone 93. Spowiednik mógłby mandaty nakładać sam, co dla penitenta $w$ tej materii byłoby znacznym udogodnieniem ${ }^{94}$.

Ponieważ według Kodeksu $\mathrm{z} 1983 \mathrm{r}$. zwalnianie $\mathrm{z}$ kar w sakramencie pokuty w wypadku nagłym stwarza poważne problemy natury duszpasterskiej, zaczęto postulować; aby ordynariusze miejsca udzielali spowiednikom władzy uwalniania od kar poprawazych latae sententiae $z$ jednoczesnym prawem nakładania mandatów ${ }^{05}$. Można powiedzieć, że w tym kierunku zmierza cała praktyka duszpasterska realizowana przez biskupów diecezjalnych, czego wymownyrn przykładem jest uchwała (,zalecenie") sesji plenarnej Konferencji Episkopatu Polski $z$ dnia 29 marca $1984 \mathrm{r}$. oraz dekret biskupa diecezji Fulda w RFN z dnia 26 kwietnia $1985 x$.

Konferencja Episkopatu Polski na sesji biskupów diecezjalnych, dążąc do ujednolicenia uprawnień $w$ kwestii zwalniania $z$ ekskomuniki latae sententiae za przestępstwo przerywania ciąży, okresliła osoby, które winny otrzymać jurysdykcje do zwalniania ze wspomnianej ekskomuniki. Oprócz tego przewidziano liczne okoliczności dotyczące miejsca, czasu i osób, kiedy absolucji tej może udzielić każidy spowiednik ${ }^{\mathbf{6}}$.

Biskup Fuldy upoważnił natomiast wszystkich spowiedniliów zachodniej części swojej diecezji do udzielenia $w$ sakramencie polauty absolucji od kary ekskomuniki za przestępstwa wymienione w kaǹ. $1364 \S 1$ (apostazja, herezja i schizma). Ponadto akreślił sposób postępowania $w$ takim wypadku. Przed udzieleniem rozgrzeszenia penitent winien zlożyć wobec spowiednika wyznanie wiary, przyxzec, że nigdy nie odstapi od Kościola oraz zobowiązać się do naprawienia zgorszenia. Następnie spowiednik ma nałożyć surowe pokuty, kstóre należy dostosować do osoby penitenta. Ponieważ znajomość udzielonej absolucji pochodzi ze spowiedzi, fakt jej udzielenia na tej podstawie nie może być wpisany do akt parafialnych. Dlatego tez $w$ przypadku publicznym, co zawsze ma miejsce przy występowaniu z Kościoła, spowiednik musi upomnié penitenta, aby powiadomił swojego proboszcza o

93 Communicationes 9 (1977) 322.

$94 \mathrm{P}$. Hempere $\mathrm{k}$, Ograniczenie wtadzy rozgrzeszania $z$ racji grzechów $i$ cenzur koscielnych $w$ świetle prac nad reformq prawa kanonicznego, s. 58.

${ }_{95}$ W. Góralski, Wradza spowiednika w zakresie odpuszczania grzechów i kar wedtug nowego Kodeksu Prawa Kanonicznego, Prawo Kanoniczne 27 (1984) $\mathrm{nr}$ 3-4, s. 86-87; J. S y y jczyk, Sakrament pokuty w karnym prawie kanonicznym, s. 285.

96 Poszczególni biskupi diecezjalni zgodnie z powyższym „Zaleceniem Konferencji Episkopatu Polski" upoważnili spowiedników do udzielania absolucji od wspomnianej ekskomuniki, co powinno być oceniane według decyzji poszczególnego biskupa. Zob. Kielecki Przegląd Diecezjalny 60 (1984), s. $113-114$. 
otrzymanej absolucji i poprosil go o odnotowanie tego faktu w aktach parafialnych $\mathbf{8 7}$.

Z przytoczonych przykładów wynika. że ordynariusze uprawnieni do zwalniania $z$ ekskomuniki latae sententiae nie obawiaja sie delegować spowiedników do zwalniania $z$ tej kary $w$ sakramencie pokuty. Czynia to przede wszystkim powodowani troskaz duszpasterską o dobro duchowe swoich wiernych. Praktyka pastoralna i racje do tego skłaniające zmierzają w przeciwnym kierunku nizz wyrazil to Projekt z 1973 r., w którym karę ekskomuniki chciano cakkowicie odsunąc od sakramentu pokuty. Poza tym IKodeks z $1983 \mathrm{r}$. W dziedzinie zwalniania z kar dopuszcza dwojakie rozwiązanie, jeżeli kara latae sententiae nie zostala jeszcze deklarowana. Po pierwsze można ściśle przestrzegać zasady, że dokonuje się ono $z$ reguly $w$ zakresie zewnętrznym. Po drugie - mozna zagadnienie to mocniej powiązać z zakresem wewnętrznym $\mathrm{w}$ granicach prizewidzianych prawem. Wyraźnie potwierdzają to wyżej przytoczone przykłady.

W świetle tego, co dotychczas powiedziano, należy stwierdzić, że w praktyce caly cięzar zwalmiania z kar poprawczych ekskomuniki i interdyktu latae sententiae spoczywa na spowiednikach. Budzi to jednak powazne zastrzeżenia. Spowiednik zobowiązany jest bowiem do prizyjęcia na siebie funkcji sędziego kościelnego a wypelnianie $w$ sakramencie pokuty zadań sędziego nastręcza przecieź wiele trudności. Wiele zasad, warunków i okoliczności, jakie przewiduje prawo odnośnie do wymiaru cenzur latae sententiae, w sposób właściwy może być przestrzeganych tylko przez sędziego, który sprawę rozstrzyga w zakresie zewnętrznym. Natomiast zwalnianie $\mathrm{z}$ kar $\mathrm{w}$ sakramencie pokuty wymaga, aby spowiednik był równie biegły w kanonicznym prawie karnym, jak sędzia wykonujący swoją władzę $w$ zakresie zewnętrznym. Właśaiwie powinien on być nawet lepszym znawea dyscypliny karnej, gdyż nie dysponuje takim czasem, jak sędzia rozwiązujący konkretmy przypadek w zakresie zewnętrznym oraz posiada bardzo skromne śnodki, za ponoca których może ocenić falyty ${ }^{83}$.

Przy zwalnianiu $z$ kar w sakramencie pokuty istnieją więc normy prawne, których spowiednik nie zawsze będzie mógł przestrzegać i dlatego istnieje realne niebezpieczeństwo ich zaniedbywania. U spowiednika rodzą się pytania, na które trudno jest dać właściwą odpowiedź: jak należy postąpić, gdy penitent i spowiednik mają przeszkodę do wniesienia rekursu po mandaty?; czy penitent musi się odnieść po mandaty do przełożonego w za-

97 Dekret des Bischofs von Fulda vom 26. April 1985 über die Absolution von den Zensuren des c. $1364 \$ 1 \mathrm{CIC}$ (wegen Apostasie, Ireesie und Schisma), ABI 101 (1985) 30. Przytaczam za: Archiv für katholisches Kirchenrecht 154 (1985), s. $199 \longrightarrow 200$.

${ }_{98} \mathrm{P}$. $\mathrm{Hu} \mathrm{izi} \mathrm{g}$, De iudico poenali in foro poenitentiali, 268-269. 
kresie zewnętrznym, jeżeli $z$ pewnością narazi go to na zniesławienie?; jak mają wybrnąć $z$ sytuacji spowiednik i penitent, a nawet przelożony zakresu zewnętrznego, jeśli pomiędzy zakresem wewnętrznym i zewnętrznym dochodzi do konfliktu?

Oprócz tego powstają inne wątpliwości, które wynikają z przeglądu norm dotyczących zwalniania $z$ kar w sakramencie polkuty. Obowiązek odniesienia się po mandaty spoczywa nie tylko na uwolnionym od cenzur w wypadku naglym, ale także na tym. który powrócil do zdrowia, jeśli a'solucję otrzymal w niebezpieczeństwie śmierci. Jeżeli cenzura została wymierzona lub deklarowana albo jest zastrzeżona Stolicy Apostolskiej, rozgrzeszony w niebezpieczeństwie śmierci po wyzdrowieniu ma obowiąze odwołania się po mandaty ${ }^{99}$. Obowiązku tego nie przewiduje sie, gdy kara nie jest deklarownana i nie zostala zastrzeżona Stolicy Apostolskiej, co np. może mieć miejsce w przypadku przestępsíwa przerwania ciąży. Obowiązek natomiast wniesienia rekursu spoczywa na uwolnionym od powyższej kary w wypadku nagłym. $Z$ punktu widzenia racji pastoralnych trudno jest doszukać się jakichkolwiek podstaw takiego zróżnicowania. Nie widać również racji duszpasterskich uzasadniających stanowisko Kodeksu z 1983 r., że w wypadku nagłym spowiednik nie może wwolnić penitenta od cenzur juz wymierzonych lub deklarowanych 109.

\section{Wrioski koneowe}

Z rozważań prżeprowaidzonych nad pastoralnym charakterem eksskomuniki w świetle Projektu z 1973 r. i Kodeksu z 1983 r. można wysnuć wniosek, że z duszpasterskiego punktu widzenia kara ta $\mathrm{w}$ obecnie obowiązującym prawie jest bardziej korzystna niż wyraził to wspomniany Projekt. Wniosku tego nie należy jednảk utozsamiać $\mathrm{z}$ twierdzeniem, że elkskomunika w świetle przepisów kodeksowych nie budzi żadnych poważnych zastrzeżeń. Wręcz przeciwnie - rodzi ona wiele krytycznych uwag, lecz sa one mniejszej wagi niż zarzuty kierowane przeciwko propozycji przedłożonej $\mathrm{w}$ Projekcie z $1973 \mathrm{r}$.

Kodeks z 1983 r., nawiązując do pojęcia ekskomuniki funkcjonującego w Kodeksie z 1917 r., w kansekwencji musiał w pewnym sensie odstąpić od zasady wyrażonej w Projekcie z 1973 r., a dotyczącej ograniczenia prawa karnego do zakresu zewnętrznego. Ustawodawca zasady tej nie odrzucił jednak calkowicie, albowiem $\mathrm{w}$ obecnym prawie zwalnianie $\mathrm{z}$ kar jest mocniej związane $z$ zakresem zewnętrznym, niż wyraził to poprzedni Kodeks. Ocena pastoralna ekskomunikj skłania również do wypowiedzenia uwag dotyczących koncepcji absolucji $z$ cenzur przyjętej w obo-

${ }^{99} \mathrm{Kan} .1357 \S 3$.

${ }_{100} \mathrm{P}$. H u izing, De iudicio poenali in foro poenitentiali, s. 269. 
wiązującym prawie. W materii zwalniania $z$ kar poprawczych Kodeks z $1983 \mathrm{r}$. przyjął podwójny system. W zasadzie absolucja $z$ cenzur dokonuje się $w$ zakresie zewnętrznym. W wielu wypadkach - chociaż wyjątkowo - możliwe staje się ono również w zakresie wewnętrznym, czyli sakramentalnym. Jest to więc stanowisko zbieżne z Kodeksem z 1917 r. Jednakże zasady dotyczące zwaliniania $z$ cenzur w zakresie wewnętrznym zawarte $w$ Kodeksie z 1983 r. stwarzaja więcej niejasnych i kantrowersyjnych problemów niż wynikało to $\mathrm{z}$ postanowień poprzedniego Kodeksu. Wreszcie upoważnienie spowiedników do zwalniania z ekskomuniki latae sententiae w sakramencie pokuty - chociaż podyktowane względami duszpasterskimi - powoduje, że ekskomunika zatraca swój karny charakter.

Conceptus excommunicationis sub lumine officiorum pastoralium Ecclesiae in Schemate iuris poenalis anno 1973 elaborato et in Codice Iuris Canonici anno 1983 promulgato obvius

Hoc articulo de effectibus excommunicationis, prout illi in Schemate iuris poenalis anno 1973 elaborato et in Codice Iuris Canonici anno 1983 promulgato exponuntur, pastorali Ecclesiae officio respecto, tractatur. Quod ad pastoralem animarum curam pertinet, excommunicatio in Cadjice Iuris Canomici hoc tempore vim suam obatinenti ad praxim et viitam Eccliesiae aptior evadit, quam illa, quae in Schemate supra laudato exposita est. Excommunicatio, ex qua quis ad Sacramentum Poenitentiae accedere non prohibetur, simul etiam Sacram Communionem accipere vetatur (iuxta Schema anno 1973 elaboratum), eo tantum spectat, ut reus, utpote societatis membrum, emendetur. Praeterea talis excommunicationis conceptus discrimen inter censure et poenas expiatorias tollit.

In Cadice Iuris Canonici anno 1983 edito poena excommunicationis eo constituta est, ut reus sensu theologico emendaretur, et haec poena a poenis expiatoriis longe diversa est.

At tamen talis excommunicationis conceptus, qualem lin Cadice Iuris Canonici anno 1983 invenimus, saepe reprenditur et a mulitis coarguitur, praesertim in inis, quae ad remissionem censurae in Sacramento Poenitentiae attinent. Omnes hic fere animadversiones repetuntur. quae in recensendo Codice Iuris Canonici anno 1917 edito afferebantur. Praeterea ex remissione censurae in foro interno (sacramentali) concessa, iuxta Codicem Iuris Canonici anno 1983 promulgatum, plures controversiae et dubia oriuntur, quam quae ex canonibus CIC/1917 in lucem orilebantur. Denique remissio excommunicationis latae sententiae a confessariis concessa, etsi rationes pastorales id suadeant, efficit, ut excommunicatio suo poenali charactere privetur. 